ЕКОНОМІКА ТА УПРАВЛІННЯ НАЦІОНАЛЬНИМ ГОСПОДАРСТВОМ

UDC $340(477)$

H. V. Zadorozhnia, Doctor of Juridical Sciences, Associate Professor, Yu. A. Zadorozhnyi, Candidate of Juridical Sciences, Associate Professor, O. M. Sobovyi, Candidate of Juridical Sciences

\section{CONTROL IN THE SYSTEM OF PUBLIC ADMINISTRATION}

Urgency of the research. The relevance of the study of control in the system of public administration is caused by the monopolization of state power in Ukraine.

Target setting. The legislation of the world countries is extremely vague in terms of selection and systematization of rules of law that determine the controlling competence of the President. In addition, this type of control is virtually unexplored in the science.

Actual scientific researches and issues analysis. Many modern scientists (A. Boyko, O. Voloshchuk, N. Koval, S. Seryogina, T. Skomorokha V. Sukhonos, A. Shatilo, $V$. Shapoval) studied the institution of head of the state.

Uninvestigated parts of general matters defining. Outside the field of view of scientists was such an important question as the control, the subject of which is the head of the state, although the head of the state has significant powers in the sphere of economic policy in many countries.

The research objective. The article aims to explore the content and forms of such control, formed in case of necessity of proposals on optimization of these relations in the national public administration.

The statement of basic materials. In the article is set the features and the main forms of control competence of the head of the state, defined conceptual approaches to the practical implementation of this competence.

Conclusions. The practical implement-tation of the control competence of the head of state must be provided by the system of political, economic and legal guarantees.

Keywords: control; state administration; a head of the state; veto.

DOI: 10.25140/2410-9576-2017-1-4(12)-161-164

Urgency of the research. The state as a complicated political-territorial organization with multiple hierarchical, interdependent, and additional political, economic, financial, tax, legal systems and relations can not exist outside the legal control. Therefore, state control exists in any state system. Feature of the control is that it has a limited objective manifestation (content) and objectivizes in certain forms (financial, administrative, technical, economic, etc.). Therefore, control cannot be studied in «isolation» from certain economic or political system within which it operates.

Target setting. A head of state as a public authority is one of the subjects of such control, however, this type of control is virtually unexplored in science. In addition, the legislation of the world countries is extremely vague in terms of selection and systematization of rules of law that determine the controlling competence of the President. For example, the King of Saudi Arabia is obliged to exercise supervision over compliance with the Islamic Sharia, but the law does not define a specific list of actions aimed at achieving this goal. Ukraine is no exception (article 102 of the Constitution of Ukraine).

Actual scientific researches and issues analysis. Many modern scientists (A. Boiko, O. Voloshchuk, N. Koval, S. Seryogina, T. Skomorokha, V. Sukhonos, A. Shatilo, V. Shapoval) studied the 


\section{ЕКОНОМІКА ТА УПРАВЛІННЯ НАЦІОНАЛЬНИМ ГОСПОДАРСТВОМ}

institution of head of the state. Scientific studies of these scientists are basically outlined by the theoretical advances of the Institute of the head of the state, as well as by in-depth analysis of certain aspects of its legal status: powers of the President, the order of taking up a post by him, the legal acts of the head of the state.

Uninvestigated parts of general matters defining. However, outside the field of view of scientists was such an important question as the control, the subject of which is the head of the state, although the head of the state has significant powers in the sphere of economic policy in many countries.

The research objective. The objective of this publication is to implement a comparative analysis of legislation and state-forming practice in terms of control, the subject of which is the head of the state in Ukraine and foreign countries, and the goal is to identify the content and forms of such control formed in case of necessity of proposals on optimization of these relations in the national public administration.

The statement of basic materials. The term "control» comes from the Latin «contra rotulus» (from which was formed the French word «control») that means «comparison or contraposition» [1, p. 124], taking into account the activities of someone, something or supervise someone, something, to check the compliance of an object with established requirements [2, p. 569]. So, "control» must be understood as a certain comparison of something, it can only be substantive, that is, be addressed to certain social relations, such as economic.

A legislator giving the President such status as «Garant», «leader», «symbol» should give him a real opportunity, by providing his competence with content, to influence the economic, social, political and other processes in society. The law should contain a list of components of control competence of the head of the state and to regulate the mechanism of their practical implementation, which will stipulate an equation of the status identification of the President with his functionality. Therefore, granting the head of the state of control jurisdiction and the establishment of a mechanisms for its implementation is one of the manifestations of ensure its effectiveness in the mechanism of state power.

Control is a specific type of activity, which is based on the organizing influence of one subject on another. The specificity of this effect is manifested in the social-economic and political-legal flats. The control function of the head of the state is to ensure the «legality and discipline that allows to set the compliance or noncompliance of the actual state of affairs in the public administration to the requirements established by normative legal acts» [3, p. 143]. The control competence of the head of the state is his rights and obligations, forms and methods of their implementation in the field of supervision and inspection over the activities of certain entities of public authorities and their officials. The content of the control competence of the head of state consists of political-legal, social-economic, organizational, procedural and other impacts on entities of public and law relations. Therefore, the question arises: in what forms and to what entities the head of the state may exercise the control?

One of the forms of control competence of the head of the state is the repeal of acts of bodies of Executive power. So, the President of Azerbaidzhan is authorized to cancel decisions and orders of government, acts of central and local executive authorities. However, the limits of control competence of the President in Ukraine does not cover the legal relations connected with the abolition of the acts of the government.

The second form of the control competence of the head of the state is imposition a veto on government decisions. Difference the veto of the repeal of the acts is that the head of the state imposes veto only on those government decisions (including in economic issues) that have not entered into force, the cancellation process involves the commission of acts aimed at the force loss of the existing acts. So, the President of Cyprus has the right of final veto in respect of decisions of the Council of Ministers for foreign Affairs, defense or security of the state, and is also authorized to turn to the rereview of a decisions of the government on these issues. With regard to control competence of the President of Ukraine about the government, he may suspend force of acts of the government in Ukraine (article 106 of the Constitution of Ukraine), referring the Constitutional Court of Ukraine.

The third form of the control competence of the head of the state is constitutionally enshrined right of the head of the state to obtaining the information that corresponds to the obligation of other governmental bodies to provide it. Thus, the right to receive a report from the government has the Presi- 


\section{ЕКОНОМІКА ТА УПРАВЛІННЯ НАЦІОНАЛЬНИМ ГОСПОДАРСТВОМ}

dent of Israel. A variation of this imperative informing of the head of the state is a report. The President of Ukraine has also the right to participate in government meeting and to make proposals aimed at optimization of economic, investment, and other climate in the state.

The fourth form of the control competence of the head of the state is the early termination of powers of the Parliament that is in Bulgaria, Greece, Spain, Italy, Jordan, Netherlands, Serbia, Syria, East Timor, Hungary, Ukraine, Peru, etc. The President of Bulgaria is authorized to terminate the powers of Popular Assembly in case of their failure to form a government. The President of Serbia has also the right to early terminate the powers of the National Assembly from most of these bases. At the same time, President of Italy may terminate the powers of the Parliament as a whole or one of its Chambers after consultation with the chairmens of the Chambers. But the King of Jordan acts discretely in the process of implementation of his control competence. The President of Ukraine is also vested with control competence as to Parliament, he may terminate the powers of the Parliament in advance (articles 90,106 of the Constitution of Ukraine).

The fifth form of the control competence of the head of the state is imposition of veto on laws passed by Parliament, which takes place in such countries as Azerbaidzhan, Bulgaria, Guatemala, Honduras, Greece, Italy, East Timor, France, Mongolia. But the head of the state in Iceland has the right to reject a law approved by Parliament, which predetermines its approval in a referendum. The President of Cyprus has the right to return «any law or decision, as a whole or partly, to the House of representatives for review» (article 51 of the Constitution of the Republic of Cyprus of 16th of August 1960), but the Parliament can override of a veto of the head of the state. The right of veto over laws passed by Parliament (except for laws on amendments to the Constitution) is one of forms of control competence of the President of Ukraine, which is actively using its right that, on the one hand, hinders the adoption of necessary laws, and on the other hand, encourages Parliament to enhance their quality.

The sixth form of the control competence of the head of the state is a right of recourse of President to a court (Supreme Court, Constitutional Court). The subject of recourse to a court is, as practice shows, a request of the head of state about check on conformity of a certain legal act as a whole or its certain provisions with the Constitution (the Principality of Andorra, East Timor).

The President of Ukraine is endowed with the same control competence. There is a trend according to which the number of constitutional petitions of the head of the state to the authority of constitutional jurisdiction increases during periods of economic and political crisis and decreases in terms of economic and political stabilization. In in Ukraine in 2006 - 2016. During $2010-2016$ number of constitutional applications, the author of which was the head of the state has significantly decreased in comparison with $2006-2008$.

Early termination of powers of government is the seventh form of the control competence of the head of the state. This form of control is set in Lithuania, East Timor. The President of Ukraine may only initiate the consideration of an issue of the government's responsibility and adoption of a resolution of no confidence at the Parliament according to the Constitution of the state. Therefore, the implementation of the control competence of the head of the state in Ukraine, which envisages the resignation of the government, is only possible in conjunction with the Parliament. However, the control competence of the President of Ukraine governs to other bodies of state Executive power. The chairmen's of local state administrations are responsible to the President of Ukraine who has the right to cancel the decisions of heads of local state administrations that contravene the legislation of Ukraine. So, the control competence of the head of the state governs almost the entire vertical of Executive power.

The constitutions of some countries set other forms of control competence of the head of the state. So, the Union Council as a collegial head of Switzerland may raise objections against the economic treaties of the cantons concluded between them or with other countries, and is authorized in the exercise of its Supervisory jurisdiction «to handle complaints». The control competence of the head of the state is sometimes shaped with such areas as natural resources of the state, Finance (Guatemala). Therefore, the implementation of the control competence of the head of the state is carried out in various forms and in relation to the various subjects of constitutional relations, which are the state authorities, their officials and the like. 


\section{ЕКОНОМІКА ТА УПРАВЛІННЯ НАЦІОНАЛЬНИМ ГОСПОДАРСТВОМ}

An important factor in control effectiveness, a subject of which is the head of the state, are guarantees (political, economic, and legal). Political guarantees of control competence of the head of the state are the legally permissible political conditions and ways of realization of this competence by him in full. However, in terms of military aggression against Ukraine the political guarantees of the control competence implementation of the head of the state are not ensured on the entire territory of Ukraine. Economic guarantees of control competence of the head of the state are in providing the state with the obligation and financial and material conditions that are necessary to fulfill this competence by him. For example, the allocation funds provided in the State budget for the establishment of consultative, advisory and other subsidiary bodies and services (article 106 of the Constitution of Ukraine).

Legal guarantees of the control competence of the head of the state are the ways established by the Constitution of the state and other normative-legal acts to ensure use, compliance, implementation and application of the law that fix its ability to implement state-imperious influence on the defined range of legal entities through the adoption of legal acts by him. Legal guarantees of control competence of the head of the state give him an opportunity to approve legal acts directly with the aim of providing procedural and practical implementation of the control competence. For example, such legal acts of the head of the state are decrees of the President of Ukraine "On the powers and guarantees of constant control implementation over activity of the Security Service of Ukraine» dated May 18, 2007, «On the non-applicability of the prohibition to hold positions in respect of which the measures on purification of government (lustration) have been implemented» from the 21th of April, 2015, "On establishing the National Anti-corruption Bureau of Ukraine» from 16th of April, 2015 and other. Legal guarantee of the control competence implementation establishes the right of the head of the state to exercise this control and to have defined freedom of actions to carry it out. Therefore, to ensure the effectiveness of the control, a subject of which is the head of the state, there are necessary political, legal and economic conditions.

Conclusions. Summarizing the results of comparative analysis of legislation and state practice in terms of controlling, a subject of which is the head of the state, we come to the following conclusions:

1) control competence of the head of the state is his rights and obligations, forms and methods of their implementation in the field of supervision and inspection of activities established by the law of subjects of public authority, in particular public authorities and their officials;

2) the main forms of control competence of the head of the state: repeal of acts of bodies of Executive power; veto imposition on decisions of the government; right to obtain information; early termination of powers of Parliament; veto imposition on the laws adopted by Parliament; recourse to a court by the head of the state; early termination of powers of the government;

3) practical implementation of the control competence of the head of the state through a system of political, economic and legal guarantees;

4) feature of control, a subject of which is the head of the state, is that only constitutional, but not administrative or criminal liability that can occur according to the results of its conducting.

\section{References}

1. Konstantinov, F. V. (Ed.). (1967). Filosovskaia entsiclopedia [Philosophical encyclopaedia]. (Vols. 1-5). Moscow: Sov. entsicl. [in Russian].

2. Busel, V. T. (Ed.). (2007). Velykyi tlumachnyi slovnyk suchasnoi yukrainskoi movy: 250000 [Great explanatory dictionary of modern Ukrainian language: 250 000]. Kyiv: Irpin: Perun [in Ukrainian].

3. Prysiazhnuk, A. Y. (2011). Orhanizatsiino-pravovi zasady derzhavnoho kontrolu u sferi vykonavchoi vlady [State control in the sphere of executive power]. Kyiv: Zolota hvylia [in Ukrainian].

\section{Література}

1. Философрская энциклопедия : в 5 т. / глав. ред. Ф В. Константинов. - М. : Сов. энцикл., 1967. - Т. 2. - 576 с.

2. Великий тлумачний словник сучасної української мови: 250000 / уклад. і голов. ред. В. Т. Бусел. - К. : Ірпінь: Перун, 2007. - 1736 с.

3. Присяжнюк, А.Й. Організаційно-правові засади державного контролю у сфері виконавчої влади: монографрія / А.Й. Присяжнюк. - К.: Золота хвиля, 2011. - 398 с.

Received for publication 10.01.2017

Бібліографічний опис для цитування :

Zadorozhnia, H. V. Control in the system of public administration / H. V. Zadorozhnia, Y. A. Zadorozhnyi, O. M. Sobovyi // Науковий вісник Полісся. - 2017. - № 4 (12). Ч. 1. - С. 161-164. 